\title{
Ovarian ectopic pregnancy: a case report with review of literature
}

\author{
Meena P' ${ }^{1}$, Bhojwani $\mathbf{P}^{2}$, Verma G.S \\ ${ }^{1}$ Dr. Pragati Meena, ${ }^{2}$ Dr. Poonam Bhojwani, ${ }^{3}$ Dr. Gajendra Singh Verma, all authors are affiliated with Department of \\ Obstetrics \& Gynecology, NIMS Medical College and Hospital, Shobha Nagar, Delhi Highway Jaipur, Rajasthan, India.
}

Address for Correspondence: Dr. Pragati Meena, Email: pargatim@gmail.com

\begin{abstract}
Background: Ectopic pregnancyis a major health issue in reproductive age group female. Incidence of primary ovarian ectopic pregnancy as mentioned in literature of India is variable from $0.001 \%$ to $0.014 \%$ of normal pregnancies. Only $0.15 \%$ to $3.0 \%$ of all ectopic pregnancy occurs in ovary and it is $2^{\text {nd }} \mathrm{m} / \mathrm{c}$ site of ectopic pregnancy after fallopian tube. Annual incidence ofextra uterine cavity pregnancyis rising over past 3 yrs. Aim and Objective: Aim of this review article is basically to describe a case of ovarian pregnancy and to study by a review of literature, the clinical sign \&symptoms, diagnostic criteria and management of particular pathlogy accordingly, promote conservative surgical management. CASE-Here we report a case of 28 years old women, G5P3L3A1, presented to our hospital withlower abdomen pain with one and half month pregnancy with clinical feature of shock. Diagnosis was confirmed by transvaginal ultrasound, patient was prepared \& taken for laparotomy in view of ruptured ovarianectopic pregnancy. Her intraoperative findings were $200 \mathrm{cc}$ hemoperitoneum present, salpingo-oophorectomydone on Rt side. Tubal ligation done on left side by modified pomeroy method. Postoperative period was uneventful. Her histopathological report shows ovarian tissue in wall of gestation sac. Conclusion: According to spigelbergcriteria,it is a diagnostic challenge to obstetrician. Diagnosis can be missed radiologically and intraopertively. It Should be suspectedinpatients presented with rupturedec topic pregnancy, ultrasound features suggestive of normal b/lfallopian tubewith hemoperitoneum with breached ovarian surface. Conservative surgical approach is preferred, Now days Medical management is preferred for unruptured ectopic pregnancy. Confirmation of ovarian pregnancy done only after histopathologicalreport
\end{abstract}

Keywords: Ectopic pregnancy, Laprotomy, Salpingoophorectomy,Methotrexate

\section{Introduction}

The Incidence of ectopic pregnancy is $1.2-1.4 \%$. Incidence of primaryovarian ectopic pregnancy as mentioned in literature of India is variable from $0.001 \%$ to $0.014 \%$ of normal pregnancies. Only $0.15 \%$ to $3.0 \%$ of all ectopic pregnancy occurs in ovary and it is $2^{\text {nd }}$ $\mathrm{m} / \mathrm{c}$ site of ectopic pregnancy after fallopian tube [1]. Extra-iterine pregnancy or ectopic ovarian pregnancy a greek word originated from "EKTOPOS" which means out of place. Ektopos refer toimplantation of blastocyst outside of uterine cavity [1]. Primary ovarian ectopic pregnancy is very rare clinical presentation of extrauterinepregnancy \& very dangerous lifethreatening emergency if not diagnosed timely. Fallopian tube is most common site of ectopic pregnancy, comprises to $95 \%$ of total ectopic pregnancies. Incidence increasing with ART proceduresand IUCD insertion. Ovarian pregnancy is

Manuscript received: $30^{\text {th }}$ July 2017

Reviewed: $8^{\text {th }}$ August 2017

Author Corrected: $14^{\text {th }}$ August 2017

Accepted for Publication: $18^{\text {th }}$ August 2017

Obsgyne Review: Journal of Obstetrics and Gynecology gestational sac implantation in the ovary.First case of ovarian pregnancy is reported by St. Maurice in 1689 . Its diagnosis is very difficult \& based on clinical diagnosis, intraoperative finding and on histopathological report. Definite management of ruptured ovarian pregnancy is surgery. Approximately 75\% pregnancies terminate in early gestation $12.5 \%$ patients terminates in the second trimester \& $12.5 \%$ patients reached till term. Ovarian pregnancyin 1624, suggested first by Mercerus[2,3].

Incidence of ectopic pregnancy is-

1. Tubal pregnancy- $90-95.5 \%$

2. Ovary-1.5- 3\%

3. Abdomen- $1.3 \%$

4. Cervical $-0.15 \%$

5. Heterotopic $1-2 \%$

6. Caesarean $-6 \%$

7. Interstitial $-2.5 \%$ 
Original Research Article

\section{Case Report}

-28 years old female, she is $\mathrm{G}_{5} \mathrm{P}_{3} \mathrm{~L}_{3} \mathrm{~A}_{1}$ presented to our NIMS hospital emergency with complaints of amenorrhea of one and $1 / 2$ months corresponds to 6 weeks and 3 days of gestation. According to patient her previous menstrual history was normal. There was no history of PID, ART procedure, Infertility treatment, Tuberculosis. Onher examination, vitals were BP-90/60 mm of Hg, PR-110 /min, clinical features suggestive of haemorrhagic shock were present. On P/A soft distension present and tenderness in RIF.P/V examinationrevealed -uterusmobile and non-tender, cervical motion tenderness present, $2.8 \times 2.8 \mathrm{~cm}$ adnexal mass felt in right fornix.Patient investigated, her UPT $+\mathrm{ve}, \mathrm{Hb} \% 8 \mathrm{gm}$, TLC 10,600/cumm, rest hemogram was normal, USG findingswere uterine cavity Empty \& bulky ET-19 mm, 2.8x2.8 cm with out fetal pole, freefluid was present in POD.

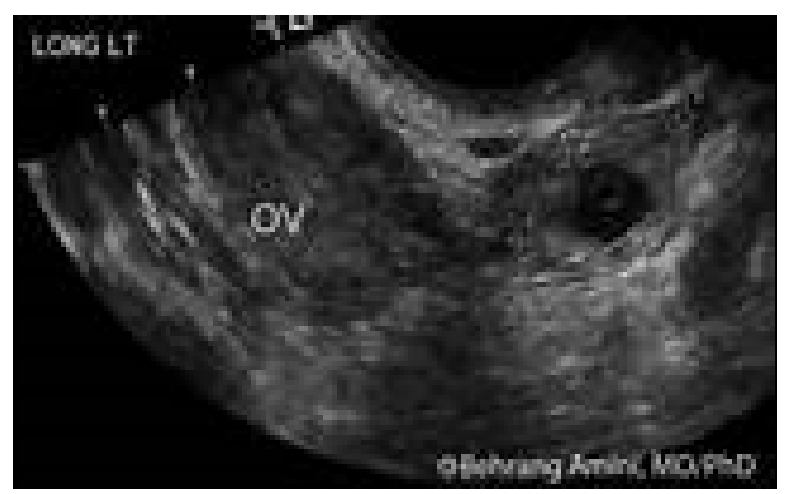

Figure-1: Ultrasound showing ovauran ectopic pregnancy

Our provisional diagnosis was ruptured ectopic pregnancy \& patient was prepared for laparotomy, her intraoperative findings-

$\checkmark$ Hemoperitoneum of $200 \mathrm{cc}$ was present

$\checkmark$ Uteruswas bulky

$\checkmark \mathrm{B} / \mathrm{L}$ fallopian tubes normal \&left ovary normal

$\checkmark$ Rt ovary enlarged with $2.8 \times 2.8 \mathrm{~cm}$ size adnexal mass in situ, bluish red in color with bleeding frombreached ovarian surface.

Right salpingo-ooporectomy done.Left side tubal ligation done by modified pomeroy's method and tissue sent for histopathologicalexamination. Her postoperative period was uneventful. Her histopathological report shows corpus luteum with trophoblastic villi in the ovarian tissue.Histopathological report of her D\&C tissueshowsabsence of villous or fetal tissue.

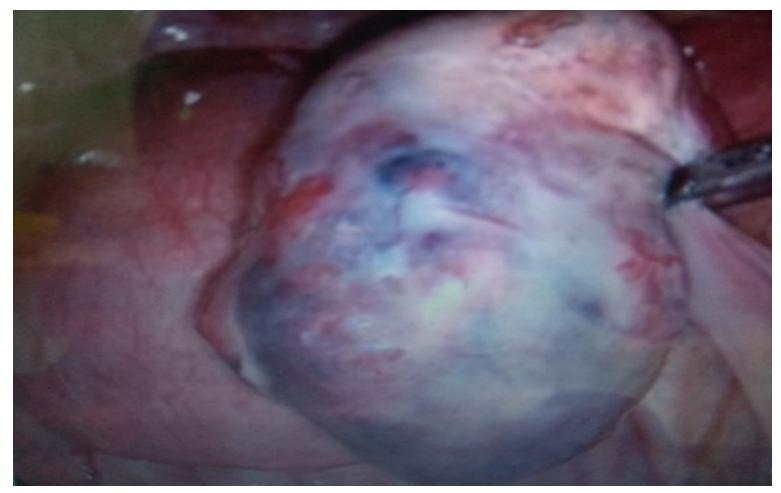

Figure 2: Intraoperative finding showing ovarian pregnancy

Histopathology report \& her intraoperativefindings were satisfied with the spigelberg criteria. Her immediate and long term postoperative course was uneventful .Patient followed up in OPD after 1 week of surgery. Her serial $\beta$ hcg was on D5 -500miu/ml, D12 -30miu/ml, D19- undetectable. 


\section{Original Research Article}

\section{Discussion and Review of Literature}

Clinical presentation of primary ovarian ectopic pregnancy is variable. This is a life-threatening emergency. Etiology of ovarian ectopic pregnancy still remain obscure. A study done by goyal et. al concluded that incidence of ovarian pregnancy is $4.8 \%$ of all pregnancies. $94 \%$ patients diagnosed in first trimester, in $11 \%$ cases preoperatively diagnosed only [3,4]. Increase incidence with ART procedures [due to increase progesterone from corpus luteum, ovarian hyper vascularity due to hyper stimulation], PID, previous pelvic surgery, PCOD, fibroid uterus. IUCD is found in $15-32 \%$ of patients of non ovarian ectopic pregnancy. $60-92 \%$ of patient of ovarian ectopic pregnancy. Grimes et. al studied 24 case of ovarian pregnancy \& concluded greater then $50 \%$ cases had infertility or failed ART $(4,5)$.

Cigarette smoking also interferewith tubal motility and ovum pickup. There is usually delay in diagnosis because Gestation sac of ovarian ectopic pregnancy in ultrasound mimic to haemorrhagic cyst of ovary, corpus luteal cyst, endometrioma of ovary. Diagnosis confirmed by TVS and CT scan. Ovarian pregnancy carries higherriskof morbidity and mortality then tubal pregnancies because ovarian pregnancy located at the most vascularised site of female pelvis. Uteroovarian anastomosis of blood vessels eroded by developing chorionic villi, leads to severe haemorrhage and patient went into haemorrhagic shock [6,7].

Ovarian ectopic pregnancies diagnosed intraoperatively \&histo-pathologically fewexceptions according to spigelberg criteria. ovarian ectopic pregnancy should be differentiated from ampullary/infundibulam tubal pregnancy, in these cases ovaries may involve secondarily after tubal abortion or rupture [8].

Criteria includes:

1. Gestation sac should occupy the normal position of the ovary.

2. Gestation sac and uterus connected with each other by utero-ovarian ligament.

3. Affected side fallopian tube with its fimbria should be intact andseparate from ovary.

4. Ovarian tissue (tunica albugenia) must be present in the specimen or in the wall of gestational sac.

5. Empty uterine cavity and evidence of amniotic cavity within follicle.

3D ultrasound (TVS) help to differentiate from haemorrhagic corpus luteal cyst (8).Diagnostic features of ovarian pregnancy are-.

Sensitivity is $85 \%-92 \%$ and specificity is $99.98 \%$

1. Double echogenic ring found within hypoechoic latero-uterine mass\&echogenecity of ring is more then ovary itself (inhomogenous mass). Wideechogenic ring with an internal echolucent areas on superficial ovarian surface are also found.

2. Gestational sac found very adjacent to the ovary.

3. All around mass follicles \& corpus luteum is present as a part of ovarian cortex.

4. Empty uterine cavity \& free fluid in peritoneal caviy.(mild fluid in pod is physiological)

5. Ovarian ectopic pregnancywill move with ovary on pressure applied with transvaginal probe.

Gestation sac visualizedby trans-abdominal scan at $\beta$-hCG discriminatory zone $\geq 6500 \mathrm{miu} / \mathrm{ml}$ in 1981 .Discriminatory zone for Transvaginal ultrasound upto 1000 to $2000 \mathrm{miu} / \mathrm{ml}$. Com shock et. al studied ultrasonographic appearance of ovarian ectopic pregnancy and they concluded ovarian pregnancyis rarely identified correctlyby sonographyandit is evenvery difficultto diagnose intra operatively $[8,9]$. Ectopic pregnancy may coexist with an intrauterine pregnancy but it is very rare with incidence $1 / 40000$, diagnosis is very difficult. It is common with assisted conception. Benauereaf et. al suggested that transducer frequency from $7 \mathrm{MHZ}$ to $10 \mathrm{MHZ}$ is helpfulin improving diagnostic accuracy [9].

Ovarianectopic pregnancy classifiedinto two types -

1. Intrafollicular pregnancy- In this ovum trapped inside the follicle, mature ovum not picked up or expelled from its follicle. Sperm fertilizethe egg after entering into follicle various theories are given for explanation

$>$ Hormonal causes

$>$ Thickened tunica albugenia of the ovary

$>$ Defect in ovum pick up due to inadequate fimbria on ovarian surface 
2. Extra follicular pregnancy-mature ovum fertilized outside of ovary, implant on ovariansurfacebecause of endometrial decidual reaction.

Fe why potheses suggested, Inflammatory thickened tunica albugenia and malfunctioning of tubes. Interference of release of mature ovum from follicle.

The sign and symptom of primary ovarian pregnancy are very similar to tubal ectopic pregnancy. Very difficult to differentiate clinically from chocolate cyst, haemorrhagic cyst, tubal pregnancy.

Trophoblastic cells invade theovarian tissue on $6^{\text {th }}$ day, followed by the invasion of the ovarian artery. Although ovarian pregnancies rupture by the $40^{\text {th }}$ gestational day, reports of those progressing into the $3^{\text {rd }}$ trimester even to live births have been established.

Most of primary ectopic pregnancy usually ruptured in first trimester of pregnancy. Recurrent ectopic pregnancy is not reported yet, in contrast totubal pregnancy, $15 \%$ recurrence noted in primigravidapatients. A study done by Savita et al. according to them out of 104 patients only 94 patients had ectopic proved by histopathology and remaininghad either haemorrhagic cyst or corpus lutealhematoma. Out of 94 patients only four hadovarian pregnancy who fulfilled spigelberg criteria.

Future fertility after surgery is unaffected- Goyal et al.done aretrospectivecross - sectional study onovarian pregnancy at Government medical college \& hospital Chandigarh, they studied risk factor, incidence, diagnosis and management of ovarian pregnancy $[3,10]$.

Table No- 1: Risk factor for ovarian pregnancy.

\begin{tabular}{|c|c|c|c|c|c|c|}
\hline $\begin{array}{l}\text { S. } \\
\text { No }\end{array}$ & Age & $\begin{array}{l}\text { POG- } \\
\text { weeks }\end{array}$ & $\mathbf{O} / \mathbf{H}$ & $\begin{array}{c}\text { Past } \\
\text { history }\end{array}$ & USG finding & Management \\
\hline 1 & 22 & $9 \mathrm{wk}$ & G4P2L2A1 & IUCD-3yr & FF in POD & Excision of sac\& B/L salpingectomy \\
\hline 2 & 24 & - & G1 & $1 *$ infertility & FF in POD & Excision of sac\& $\mathrm{B} / \mathrm{L}$ salpingectomy \\
\hline 3 & 25 & $7 \mathrm{wk}$ & G5P2L2A2 & IUCD-2yr & Bhcg-2000 & Excision of sac\& $\mathrm{B} / \mathrm{L}$ salpingectomy \\
\hline 4 & 26 & Nil & P4L4 & IUCD-5yr & $4 \times 4 \mathrm{~cm}$, adnexal & Rtoopherectomy \\
\hline 5 & 23 & $36 \mathrm{wk}$ & G3P2L2 & MTP & Placenta previa & $\begin{array}{l}\text { Laprotomy with Exicion of placenta } \\
\text { delivery of baby and oophectomy }\end{array}$ \\
\hline 6 & 34 & $8 w k$ & G3P1L1A1 & -- & FF in POD, $\beta$ hcg- 1800 & Excision of sac, repair \\
\hline 7 & 23 & $9 \mathrm{wk}$ & G2A1 & -- & Lt adnexal mass, FF + & Lt oopherectomy \\
\hline 8 & 36 & $6 \mathrm{wk}$ & G4P3L3 & IUCD-5yr & $\begin{array}{c}\text { Ltovarian G. Sac, } \\
\text { ßhcg-2000 }\end{array}$ & Excision of sac \\
\hline 9 & 25 & $7 \mathrm{wk}$ & G1 & Infertility & FF in POD & Excision of sac \\
\hline 10 & 7 & Nil & P3L3 & -- & $\begin{array}{l}\text { Rt adnexal mass } \beta \text { heg- } \\
3000\end{array}$ & Excision of sac \& repair \\
\hline
\end{tabular}

A study done by Savita et al. They concluded out of 4 patient 3 patient had history of risk factor like IUCD was present.

Management- Expectant management-Success rate is $48 \%-100 \%$.

Inclusion criteria -

- Asymptomatic women with stable vitals

- $\mathrm{B}-\mathrm{hCG}<1000 \mathrm{miu} / \mathrm{ml}$

- Ultrasound findings - Size $\leq 2 \mathrm{~cm}$ and GA $<6$ weeks, Cardiac activity absent, Yolk sac and fetal polealso absent, Free fluid in pouch ofdouglas $<100 \mathrm{CC}$.

- Serum progesterone level $<3.1 \mathrm{ng} / \mathrm{ml}$

- Cooperative patient willing for follow up 
These patients followed twice weeklyon Day 3,7.

1. If $\beta$-hcg fall $>50 \%$ within a week,continue expectantmanagement

2. If $\beta$-hcg fall $<50 \%$ within a week, consider medical /surgical management.

It is most useful when initial $\beta$-hCGlevel is $\leq 1000 \mathrm{iu} / 1$ with unruptured ectopic pregnancy. Success rate is $\mathrm{b} / \mathrm{w} 50-80 \%$. According to a prospective observational study, 118 patients are on expectant management out of them $88 \%$ recovered successfully. They had $\beta$-hCG $\leq 200 \mathrm{mIU} / \mathrm{mL}$ andpatients with $\beta$-hCG level $\geq 2000 \mathrm{mIU} / \mathrm{ml}$ only $26 \%$ recovered. Favorable factors for success of expectant management areserum $\beta$-hCG level $\leq 200$, gestational age $\leq 6$ weeks \& progesterone level below $10 \mathrm{nmol} / \mathrm{L}$.

Expectant management to be stoppedif the patient is having if the $\beta$-hCG level increases or Persistantly increasing abdominal pain. To avoid rupture of ectopic pregnancy,Patient should instructto avoid vigorous physical activity sexual activity \& pelvic examination.

Medical Management- Mittal et. al first-time used injection methotrexate directly into gestational sac of ovary [11]. Kudo et. alreported first successful use of methotrexate in ovarian pregnancy. Gabbur et al. Done a retrospective analysis on MTXuse in unruptured ovarian ectopicand concluded that after single MTX injectionon D7 $\beta$-hcg levels only, predict aneed of surgery or successful treatmentnot Day $4 \beta$ hcg level [10,11].

Patient selection is very important. Methotrexate is antagonist of folic acid that impairs cellreplication \& DNA synthesis. In 1982 first time used for medical management and mode of action by killing rapidly dividing cytotrophoblasts cells at implantation [11,12].

Table No-2: Contraindication of Meth trexate treatment in ectopic pregnancy.

\begin{tabular}{|c|c|}
\hline Absolute & Relative \\
\hline $\begin{aligned} \text { i. } & \text { Hypersensitivity } \\
\text { ii. } & \text { Thrombocytopenia }(<1 \mathrm{lac} / \mu \mathrm{l}) \\
\text { iii. } & \text { Liver dysfunction }>2 \text { fold. Alcoholic liver diz. } \\
\text { iv. } & \text { Pulmonary and peptic ulcer disease } \\
\text { v. } & \text { Hematological dysfunction with bone marrow } \\
& \text { depression TLC }<1500 / \mu 1 \\
\text { vi. } & \text { Heterotopic pregnancy } \\
\text { vii. } & \text { Ruptured ectopic pregnancy } \\
\text { viii. } & \text { Lactating mothers } \\
\text { ix. } & \text { Moderate to severe anemia } \\
\text { x. } & \text { creatinine clearance }<50 \mathrm{~mL} \text { per minute per } \\
& 1.73 \mathrm{~m}^{2} .\end{aligned}$ & $\begin{aligned} \text { i. } & \text { B-hCG }>5000 \mathrm{miu} / \mathrm{ml} \\
\text { ii. } & \text { Ectopic mass }>4 \mathrm{~cm} \\
\text { iii. } & \text { Fetal cardiac activity present } \\
\text { iv. } & \text { Poor complaint patient }\end{aligned}$ \\
\hline
\end{tabular}

Patient should instruct to stop taking prenatal vitamins, Alcohol, nonsteroidal anti-inflammatory drugs \& avoid excessive sunlight (to avoid MTX induced dermatitis) and folate supplementation, as folate will counteract action of injection methotrexate.Rh status of patient must be known to determine further need of immunoglobin therpy in Rh negative patient. A meta-analysison single and multiple dose regimens done by Barnhart et al. They concluded multidose regimen is more effective $(90 \%)$ then single dose $(80 \%)$ [13,14,15].

If $\beta$ hCG is $\geq 5000$ treatment failure rate is $40 \%$. If $15 \%$ decrease occurs b/w Day 4 and Day $7, \beta$-hCG levelsmonitored weekly tillreach zero. This will takeat least five to sevenweeks.

Single dose of methotreaxate- Levin et al. done a study and concluded, out of 69 women of study group 45 patient was treated successfuly withsingle dose of injection methotrexate. before single dose of methotrexategood predictorsof successful treatment are-

If $\beta$-hCG level $\leq 1600 \mathrm{iu} /$ landincrease $\leq 14 \%$, in a day or $24 \mathrm{hr}$.

Single dose regimen associatedleast side effects. 
Original Research Article

Table No.- 3: Single dose of methotrexate treatment protocol.

\begin{tabular}{|c|c|c|c|}
\hline & $\mathbf{0}$ & 4 & 7 \\
\hline 1. Investigations & $\begin{array}{l}\text { Bhcg, CBC,ABOrh } \\
\text { LFT,RFT }\end{array}$ & Bhcg & Bhcg \\
\hline 2. Medical management & $\begin{array}{l}\text { Methotreaxate in } \\
\text { dose of } 50 \mathrm{mg} / \mathrm{m}^{2} \text { of } \\
\text { body surface area is } \\
\text { given by IM route }\end{array}$ & $\begin{array}{l}\text { Methotreaxate in } \\
\text { dose of } 50 \mathrm{mg} / \mathrm{m}^{2} \text { of } \\
\text { body surface area is } \\
\text { given by IM route }\end{array}$ & $\begin{array}{l}\text { i. If Decrease in } \beta \text { hcg }>15 \% \\
\text { between from day } 4 \text { to day } 7 \text {. } \\
\text { Moniter } \beta \text { hcg weekly till zero. } \\
\text { ii. If } \beta \text { hcg decrease }<15 \% \text { between } \\
\text { day } 4 \text { to day } 7 \text { give } \\
\text { methotreaxate }\end{array}$ \\
\hline
\end{tabular}

Two dose regime of methotrexate of ectopic pregnancy- Branhart was only one whofirst described "Double dose regimen". Hossam et al. concluded that double dose protocol is better then single dose regimen [16,17].

Table No-4: Multiple dose of methotrexate treatment protocol.

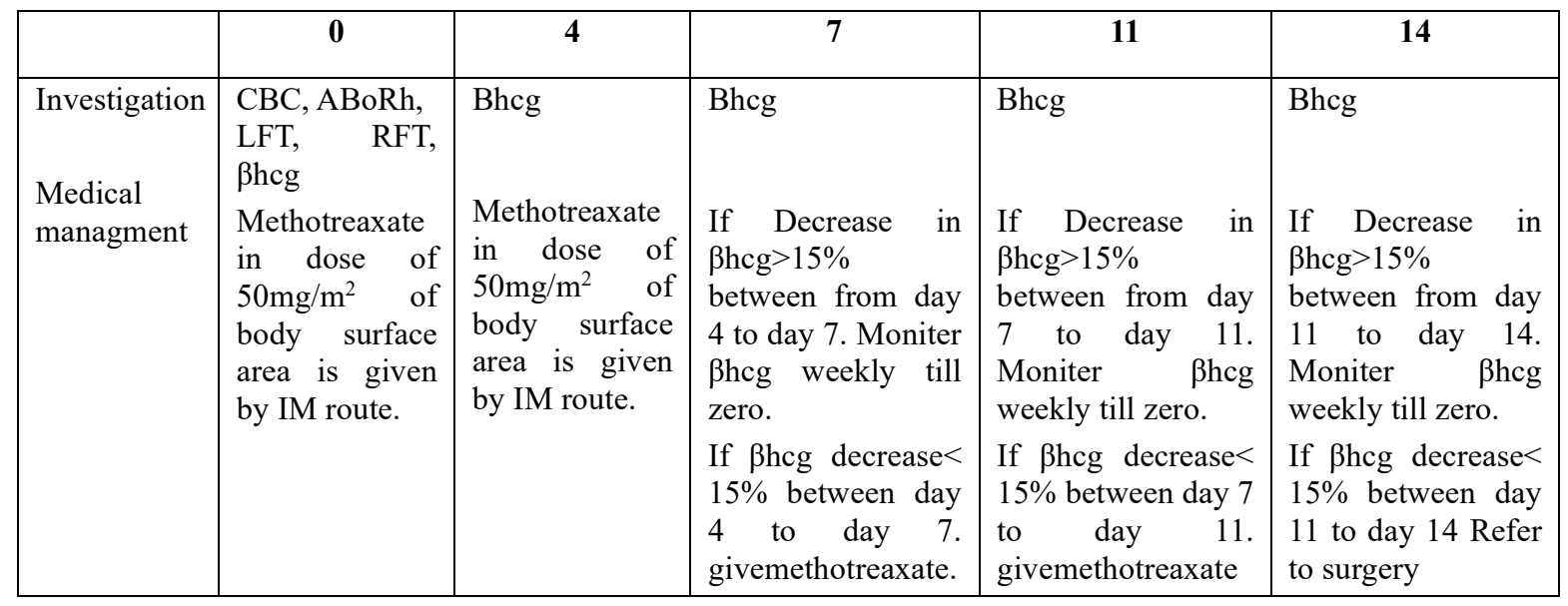

Multiple dose regime of methotrexate in ectopic pregnancy- Krik et al. concluded that multiple dose regimen is more effective then singe and double dose protocol with sensitivity $94 \%$, specificity $86 \%[1,17,18]$.

Table No-5: Double dose of methotrexate treatment protocol.

\begin{tabular}{|c|c|c|c|c|c|c|c|c|}
\hline & 1 & 2 & 3 & 4 & 5 & 6 & 7 & 8 \\
\hline $\begin{array}{l}\text { Investiga } \\
\text { tions }\end{array}$ & $\begin{array}{l}\text { CBC,AB, } \\
\text { Rh, RFT } \\
\text { LFT, } \beta \text { Hcg }\end{array}$ & & $\beta$ hcg & & $\beta$ hcg & & $\beta$ hcg & \\
\hline $\begin{array}{l}\text { Medical } \\
\text { manage } \\
\text { ment }\end{array}$ & $\begin{array}{l}\text { Methotrex } \\
\text { ate to be } \\
\text { given by } \\
1 \mathrm{mg} / \mathrm{kg} \text { by } \\
\text { IM route }\end{array}$ & $\begin{array}{l}\text { Leucovor } \\
\text { in to be } \\
\text { given by } \\
0.1 \mathrm{mg} / \mathrm{kg} \\
\text { by IM } \\
\text { route }\end{array}$ & $\begin{array}{l}\text { If Decrease in } \\
\beta \text { hcg }>15 \% \\
\text { between from day } \\
1 \text { to day } 3 \text {. } \\
\text { Moniter } \beta \text { hcg } \\
\text { weekly till zero. } \\
\text { If } \beta \text { hcg decrease }< \\
15 \% \text { between day } \\
1 \text { to day } 3 \text {. Give } \\
\text { methotreaxate. }\end{array}$ & $\begin{array}{l}\mathrm{LE} \\
\mathrm{U}\end{array}$ & $\begin{array}{l}\text { If Decrease in } \\
\beta \text { hcg }>15 \% \\
\text { between from day } \\
3 \text { to day } 5 . \\
\text { Moniter } \beta \text { hcg } \\
\text { weekly till zero. } \\
\text { If } \beta \text { hcg decrease }< \\
15 \% \text { between day } \\
3 \text { to day } 5 \text {. Give } \\
\text { methotreaxate. }\end{array}$ & $\begin{array}{l}\mathrm{LE} \\
\mathrm{U}\end{array}$ & $\begin{array}{l}\text { If Decrease in } \\
\beta \text { hcg }>15 \% \\
\text { between from day } \\
5 \text { to day } 7 . \\
\text { Moniter } \beta \text { hcg } \\
\text { weekly till zero. } \\
\text { If } \beta \text { hcg decrease }< \\
15 \% \text { between day } \\
5 \text { to day } 7 \text {. Give } \\
\text { methotreaxate. }\end{array}$ & $\begin{array}{l}\mathrm{L} \\
\mathrm{E} \\
\mathrm{U}\end{array}$ \\
\hline
\end{tabular}

Sucess rate of treatment with $\beta$ - hCG $\leq 1000 \mathrm{miu} / \mathrm{ml}$ is $87 \%$. Failure rate is $40 \%$ with level $\geq 5000 \mathrm{miu} / \mathrm{ml}$. 
Surgical Management- Primary management of Ovarian ectopic pregnancy is surgical. According to 3 prospective randomized trial laparoscopic approach is superior then laparotomy in view of less blood loss \& pain, shorter hospital stays and there is no significant difference in recurrence, subsequent intrauterine pregnancy [17,18]. Laparoscopic surgery has become preferred method \& gold standard nowdays. Conservative surgical technique like ovarian wedge resection, enucleation are also in trend now days. $80 \%$ cases managedby conservative management and radical oophorectomy done in $13 \%$ cases only. John et al. Was performed first laparotomy for ovarian ectopic pregnancy in 1759. In 1884 Robert et al. Ligatedbleeding blood vessels first time during laparotomy [4]. Shapiro and Adler introducedfirst time a laparoscopic approach in 1973 [20,21]. According to Cochrane review 2007, there is no significant difference $b / w$ systematic methotrexate and conservative surgeryif $\beta-h C G$ level $\leq 1500 \mathrm{miu} / \mathrm{ml}$. Corpus lutealcystectomy for trophoblast, curettage of trophoblast by coagulation and hemostatic suture of the bed.These are totally conservative surgeries. In case of advanced ectopic pregnancyoophorectomy or ovariectomy [22,23,24]. Recurrence ofovarian pregnancy in literature till now. Only single case reported has been reported in contrast to tubal ectopic pregnancyrecurrence rate isup to $15 \%$ [25-29].

\section{Conclusion and Perspective}

According to spigelberg criteria,it is a diagnostic challenge to obstetrician. diagnosis can be missed radiologically, intraoperatively. Ovarian pregnancy canoccur evenin Nulliparous female without risk factors like IUCD, PID, ART. Now days Medical management with single dose of Methotrexate is very successful for unruptured ovarian pregnancy. Should be suspected inpatients presented with rupturedectopic pregnancy, ultrasound features suggestive of normal b/lfallopian tube with hemo-peritoneum with breached ovarian surface. Conservative surgical approach is preferred. Confirmation of ovarian pregnancy done only after histo-pathologicalreport.

\section{Funding: Nil, Conflict of interest: None initiated,} Permission from IRB: Yes

\section{References}

1. Aetiology, diagnosis, and challenges in surgical management. J Obstet Gynaecol. 2012;32:472-4,2012.

2. Poonam Rana, Imran Kazmi, Rajbala Singh, Muhammad Afzal. Ectopic pregnancy: a review. Arch Gynecol Obstet. 2013; 288: 747-75,2013

3. Krik E, Bourne T . Ectopic pregnancy. Obstetgynecol Reprod Med 2011;21:207-211,2011.

4. Goyal Lajya Devi, M.D.,1Tondon Rimpy, M.D., 2 Goel Poonam, M.D.,2 and Sehgal Alka, M.D. Ovarian ectopic pregnancy: A 10 years' experience and review of literature. Iran J Reprod Med. 2014 December; 12 (12) : 825-830, Dec 2014

5. Fritz MA, Speroff L. Clinical gynecologic endocrinology and infertility, 8th edn. Wolters Kluwer Health/ Lippincott Williams \& Wilkins, Philadelphia. 2011.

6. Hallatt JG. Primary ovarian pregnancy: a report of twenty-five cases. Am J Obstet Gynecol. 1982;143:5560, 1982 .

7. Panelli Danielle M, H. Phillips Catherine, Brady Paula $\mathrm{C}$, Incidence, diagnosis and management of tubal and nontubal ectopic pregnancies: a review. Fertility Research and Practice 2015; 1:15,2015.

Obsgyne Review: Journal of Obstetrics and Gynecology
8. Vanitha N Sivalingam,W Colin Duncan; Emma Kirk, Lucy A Shephard, Andrew W Horne. Diagnosis and Management of Ectopic Pregnancy.J Fam Plann Reprod Health Care. 2011;37(4):231-240,2011.

9. Comstock C, Huston K, Lee W. The ultrasonographic appearance of ovarian ectopic pregnancies. Obstet Gynecol. 2005;105:42-45.2005.

10. Chang FW, Chen CH, Liu JY. Early diagnosis of ovarian pregnancy by ultrasound. Int J Gynecol Obstet. 2004; 85:186-187,2004.

11. Juan YC, Wang PH, Chen CH, Ma PC, Liu WM. Successful treatment of ovarian pregnancy with laparoscopy- assisted local injection of etoposide. FertilSteril . 2008;90:1200, 2008.

12. Mittal S, Dadhwal V, Baurasi P. Successful medical management of ovarian pregnancy. Int $\mathrm{J}$ Gynecol Obstet. 2003; 80:309-310,2003.

13. Buster JE, Carson SA. Ectopic pregnancy; new advances in diagnosis and treatment. Curr Opinion Obstet Gynecol. 1995; 7:168-176,1995.

14. Gabbur N, Sherer DM, Hellmann M. Do serum beta-human chorionic gonadotropin levels on day 4 


\section{Original Research Article}

following methotrexate treatment of patients with ectopic pregnancy predict successful single- dose therapy? Am J Perinatol. 2006. 23: 193-196, 2006.

15. Barnhart KT, Gosman G, Ashby R, Sammel M . The medical management of ectopic pregnancy: a metaanalysis comparing "single dose" and "multidose" regimens. Obstet Gynecol. 101:2003;778-784,2003.

16. Barnhart K, Hummel AC, Sammel MD, Menon S, Jain J, Chakhtoura N Use of "2-dose" regimen of methotrexate to treat ectopic pregnancy. Fertil Steril. 2007; 87:250-256, 2007.

17. Hossam O, Hamed A, Salah R, Ahmed A, Abdullah A Comparison of double- and single-dose methotrexate protocols for treatment of ectopic pregnancy. AlghashamInt J Gynecol Obstet.2012; 116:67-71, 139, 2012.

18. Kirk E, Condous G, Van Calster B A validation of the most commonly used protocol to predict the success of single-dose methotrexate in the treatment of ectopic pregnancy. Hum Reprod .2007;22:858-863,2007.

19. Bagga R, Suri V, Verma P, Chopra S, Kalra J. Failed Medical Management in Ovarian Pregnancy Despite Favorable Prognostic Factors-A Case Report. Med Gen Med. 2006;8:35,2006.

20. Habbu J, Read MD. Ovarian pregnancy successfully treated with methotrexate. JObstetGynaecol. 2006;26: 587-8, 2006.

21. Shapiro HI, Adler DH. Excision of an ectopic pregnancy through the laparoscope. Am J Obstet Gynecol. 1973;117:290-1.
22. Ayakannu T, Rogers J, Wordsworth S, Jayagopal N, Vine S. Conservative laparoscopic approach with systemic medical management of an ovarianectopic gestation. J ObstetGynaecol. 2007;27:449-50,2007.

23. Mittal S, Dadhwal V, Baurasi P. Successful medical management of ovarianpregnancy. Int $\mathrm{J}$ Gynaecol Obstet. 2003;80:309-10,2003.

24. O. Birge, M. M. Erkan, E. G. Ozbey, and D. Arslan, "Medical management of an ovarian ectopic pregnancy: a case report," Journal of Medical Case Reports. , 2015; vol. 9:1, article no. 774.,2015.

25. G. Scutiero, P. Di Gioia, A. Spada, and P. Greco, "Primary ovarian pregnancy and its management," Journal of the Society of Laparo-endoscopic Surgeons. 2012; vol. 16:3,492-494,2012.

26. Y. Koo, H. Choi, K. Im, H. Jung, and Y. Kwon, "Pregnancy outcomes after surgical treatment of ovarian pregnancy," International Journal of Gynecology \& Obstetrics. 2011; vol. 114:, 97-100, 2011

27. Chatburn Luke, SanghaniReesha, Chatburn Luke, et al. An Alternative Treatment for the Ovarian Ectopic Pregnancy.J Womens Health Gyn.2015;Vol2:102, 2015

28. Joseph RJ, Irvine LM..Ovarian ectopic pregnancy: Odejinmi F, Rizzuto MI, Macrae R, Olowu O, Hussain M. Diagnosis and laparoscopic management of 12 consecutive cases of ovarian pregnancyand review of literature. J Minim Invasive Gynecol. 2009;16:354-9, 2009.

29. Nadarajah S, Sim LN, Lo SF. Laparoscopic management of an ovarian pregnancy. Singapore Med J. 2002; 43:95-6,2002.

\section{How to cite this article?}

Meena P, Bhojwani P, Verma G.S. Ovarian ectopic pregnancy: a case report with review of literature. Obs Rev:J obstet Gynecol 2017;3(3):25-32.doi:10.17511/joog.2017.i03.03. 